\title{
Board Remuneration Transparency: A Pre and Post Analysis of MCCG 2017
}

\author{
Dayana Mastura Baharudin \\ Department of Accounting, School of Management \\ Universiti Sains Malaysia, Penang, 11800, Malaysia \\ E-mail: dayana.mastura@usm.my
}

Received: September 23, 2019 Accepted: October 18, 2019 Published: October 22, 2019

doi:10.5296/bms.v10i2.15491ＵRL: https://doi.org/10.5296/bms.v10i2.15491

\begin{abstract}
Purpose - This study investigates the impact of the three main determinants of strengthening board remuneration through Board Remuneration Committee Composition, Remuneration Composition of Directors and Top Five Senior Management Remuneration compared between pre and post MCCG 2017.

Design/methodology/approach - In order to analyze the reporting of Board compensation committee composition, compensation composition of directors and top five Senior Management Remuneration, the research will follow the purposeful technique of sampling followed by descriptive statistic, regression analysis and content analysis obtained from MCCG 2012 and MCCG2017 together with prior research findings.

Originality/value - This study is a systematic review of recent research developments in MCCG 2012 and MCCG 2017. The scoring index designed for Board Remuneration Committee Composition, Remuneration Composition of Directors and Top Five Senior Management Remuneration could also be applied to other PLCs other than the Malaysian oil and gas industry.
\end{abstract}

Keywords: MCCG 2012, MCCG 2017, Board Remuneration Committee Composition, Remuneration Composition of Directors and Top Five Senior Management Remuneration

\section{Introduction}

Overpayment of executive compensation and the compensation of directors have raised the question of absence of transparency in the data disclosed on their remuneration policy among minority shareholders, shareholder activists, regulators and the public in general (Core, Guay, 
Larcker and Schiehll, 2005).

For instance, Ezzine and Olivero (2013) proposed that the rights of minority shareholders should be protected by further pay policy data. In the financial crisis, this becomes more crucial when the majority shareholders and enterprises tend to expropriate minority shareholders ' funds via their personal profit.

Reports from company directors who receive big bonuses often trigger powerful government responses. In October 2016 Shoprite Holdings Limited in South Africa reported to receive a South African Rand 50 million performance bonus almost equivalent to their base wage, which amounts to $\$ 49.7$ million (Kew, 2016) to its Chief Executive Officer (CEO). Payment for services or jobs by executives of the board of the business or corporation shall be the remuneration of the directors. This involves the fundamental wage and other financial or non-monetary reimbursements received during the term of the executive.

After the crash of the company, executive compensation at Enron had become a central point of public interest. Not just because of the sum paid to Enron managers, such as the fact, that in 2000, CEO Kenneth Lay got more than $\$ 140$ million in complete payment, including $\$ 123$ million in stock options. The combination of "privilege inside workers walking away with stock-related profits worth hundreds of millions of dollars, whilst ordinary staff lost a substantial portion of their life savings" was only a fuel for public indignation. The fact that Enron was commonly regarded as a shining instance of efficient corporate governance, before its sudden breakdown, is perhaps the worst issue with compensation-related governance issues. After the collapse of Enron, the U.S. Senate Subcommittee determined that the company's board "tested numerous indications of questionable practices by Enron's management" and acted "to the detriment of Enron's shareholders, employees and business associates," in part by approving excessive executive compensation packages (Barney, 2009).

\section{Problem Statement}

The East Asian financial crisis of 1997-98 highlighted the weaknesses of the Malaysian corporate governance structure. It resulted in the implementation of the Malaysian Corporate Governance Code (MCCG) in 2001. It was suggested that businesses reveal the remuneration of individual directors and the reasons behind remuneration strategies.

The harmonization of Malaysian accounting standards with the International Accounting Standards occurred in 2002 but the Malaysian companies did not embrace it immediately. The Financial Reporting Standard (FRS) 2' Share-based payments was launched in 2005. It needed reporting companies to reveal information of executives ' share-based payments. The FRS 124 'Related Party Disclosure' was launched in 1999 and was modified in 2005 to include the disclosure of' key management staff 's remuneration.

The role of the Boards of Directors and the audit committee was enhanced further by the MCCG in 2012. These changes have been implemented to increase the level of transparency and restore the trust of investors in the Malaysian capital market. 
Although the amount of pay for the Malaysian executive directors was not as excessive as its Western counterparts, the Minority Shareholders Watchdog Group (2011) was concerned about the minimum amount of disclosure of remuneration policies and procedures in its annual reports. The performance of the Managing Directors and whether their remuneration is reasonable or extremely high was hard for shareholders to measure.

MCCG 2012's Principle 2 - Strengthen Composition, under recommendation 2.3 deals with the remuneration policies and procedures of directors in order to attract and retain quality directors (Securities Commission, 2012).

MCCG 2012 states that fair pay is essential to attract, maintain and motivate directors. The pay package should be aligned with the company's business strategy and long-term goals. The Board's compensation should reflect its duties, knowledge and complexity in the operations of the company. To execute this role, the Board should create a Remuneration Committee which should consist of non-Executive Directors alone or by a majority, and should, if needed, draw advice from professionals. Companies without a Remuneration committee should have board policies and processes on issues which the Remuneration committee would otherwise deal with. The annual report should disclose Board Remuneration policies and procedures (Securities Commission, 2012).

Comparatively, MCCG 2017's Principle A, which describes Board Leadership and Effectiveness further explains directors' remuneration under a sub-topic, Remuneration.

This study will investigate three new areas under MCCG 2017 which was not deliberated under MCCG 2012 such as, Board Remuneration Committee Composition; Directors Remuneration Composition and Top Five Senior Management Component.

The first problem under study as stated by MCCG 2017 is that non-executive directors should only be on the Remuneration Committee and, by a majority, independent directors should enlist assistance from experts with advice whenever necessary. Shareholding directors should not vote in order to approve their fees at general meetings. Likewise, Executive Directors should not participate in their own remuneration decisions.

The second problem under study as suggested by MCCG 2017 is that for the remuneration of individual directors, a detailed information should be available on named basis, including the compensation of individual directors comprises fees, remuneration, bonuses, benefits and other charges.

The third and last problem under investigation in this research as suggested by MCCG 2017, the Board Remuneration Committee should name the top five senior management pay components, including salary, bonuses, entitlements in kind and other emoluments in groups of RM50,000.

\section{Research Objectives}

Following are objectives of the proposed study: 
1. To measure the disclosure level of the Board Remuneration Committee Composition, Directors Remuneration Composition and Top Five Senior Management Remuneration Component's within the MCCG 2012 and MCCG 2017's across the Malaysian oil and gas PLCs.

2. To investigate the impact of the disclosure extent of Board Remuneration Committee Composition, Directors Remuneration Composition and Top Five Senior Management Remuneration Component compared between MCCG 2012 and MCCG 2017 towards the financial performance of the Malaysian oil and gas PLCs.

\section{Research Questions}

Following are the proposed questions of the study.

1. What is the disclosure level of Board Remuneration Committee Composition, Directors Remuneration Composition and Top Five Senior Management Remuneration Component during the MCCG 2012 and the MCCG 2017 era which reflects the compliance level?

2. Does the disclosure extent of Board Remuneration Committee Composition, Directors Remuneration Composition and Top Five Senior Management Remuneration Component compared between MCCG 2012 and MCCG 2017 have impact on the financial performance of the Malaysian oil and gas PLCs?

\section{Literature Review}

The financial performance of an organization is crucial to stakeholders in general and to shareholders in specific as it improves the value of the company, provides a foundation for the allocation of dividends and can be used to attract prospective buyers (Muller, 2014). The identification and analysis of factors that influence financial performance is vital, both in the theoretical and in practical aspects.

"You get the board you are paying for" (Lipman \& Hall, 2008) is said to imply that the quality of the board, and consequent value the board generates for the company, is dependent on its pay in the form of fundamental pay and retirement advantages as well as performance compensation (Gong, 2007 ; Carola \& Saks, 2010 ; Miyienda, 2010), such as bonuses and shareholding choices.

It is therefore not surprising that the compensation of the boards has risen considerably in the previous two decades, and has earned extensive media attention, regulators and proponents of voluntary implementation of codes of governance (Sheik \& Wang, 2012; Adams, 2012). (Barontini \& Bozzi, 2009).

The writers propose that the company should offer its managers an appealing package to attract and maintain skilled and well linked people to the board. However, this has not always borne fruit, as managers have in the past paid high wages, despite bad earnings that showed greed for executive or low shareholder governance (Miyienda et al, 2012). 
Therefore, there is a pressing need for risk-reduction checks and guidance has been developed beginning with the 1995 Greenbury report, which aims to achieve an equilibrium between pay and results in order to restore shareholder trust.

The financial crisis 2008-09 has raised severe concerns over the role that corporate leadership processes play in determining compensation and incentive structures, with empirical studies that show a favorable connection between the CEO and the Risk Benefit Management Board. (Fahlenbrach \& Stulz, 2011; Chesney, Stromberg \& Wagner, 2012).

Critics have essentially said that elevated rates of compensation may force managers, in the same way as we did following the collapse of WorldCom (Lublin \& Bulkeley,2006), to turn a blind eye to irregularities, as Lehman Brothers Holding has accused autonomous managers of selling big amounts of stocks before the business collapsed, to increase returns on stocks (Aebi, Sabato \& Schmid, 2011).

Different efforts have been made to regulate the significance of board compensation. The Greenbury (1995) report in the UK, for example, requested compensation to be regulated. In the United States, as in the case of significant controversies like Enron and WorldCom, the Sarbanes-Oxley Act in 2002 addressed corporate compensation (Pokrashenko 2012).

The Sarbanes Oxley Act also sought to restrict the structure of the board of directors (Chen, 2012). It is often believed that the role of the executive and non-executive directors of the company is to create value and profits for the company. There are studies that have shown a positive relationship between the remuneration of the board and the performance of the company, which is stronger for book values than for stock market measures. Industry performance also explains remuneration and provides useful information for the assessment of board behavior (Scholtz \& Smit, 2012).

All the pay rates of directors and CEOs regardless of their performance have increased exponentially (Sheik and Wang, 2012). Initiation of the Greenbury report (1995) in the UK was the first attempt to control the compensation for the director.

The connection between the salary and the executive functions of Australian banks has been studied by Doucouliagos, Askary and Haman (2006). The figures covered the period 1992-2005. The results showed that the connection between the remuneration of the director and company results was not important. If the information was lagged for two years, the board's compensation and earnings per share (EPS) were distantly related to ROE. The research also found that management strategies, bank sizes and director ownership also influence the salary level as well, in relation to performance-based pay for managers. Although the impact of board remuneration on economic performance was not demonstrated, the research found a favorable and substantial connection between CEO remuneration and bank performance.

The research by Gong and $\mathrm{Li}$ (2007) showed a favorable and substantial connection of CEO compensation with bank performance while the impact of the board remuneration on economic performance was not found. In the area of financial reporting and income management examined, the was a connection between the autonomous equity management and the efficacy 
of the board. A sample of S\&P 500 companies was used in the study. In estimating the incentives offered by Directors, the ExecuComp database of S\&P was used while the Investor Responsibility Research Center (IRRC) was used to evaluate incentives from inventory. To evaluate the connection, a regression model was used. The results showed that inventory incentives are adversely linked to the income benchmarks for meeting or beating. Evidence also revealed how autonomous managers participated in the manipulation of optional incentives and manipulation of profit on commercial stocks and the provision of stock options. Zhu, Tin and Ma (2009) was another research linked to both the pay of the director and CEO. The research shows that autonomous board managers can have a better effect on CEO's pay performance by providing data and assisting a compensation commission in developing appropriate management pay arrangements. The scientists found that when a bigger percentage of autonomous managers serve in the board, there is a important connection between CEO pay and efficiency. In those companies with a compensation committee, the association is more obvious.

The impact that corporate ownership and board remuneration has on the performance of Italian listed companies on the Milan stock exchange was examined in a new research by Barontini and Bozzi (2009). The information covered the 1995-2002 period. The research found that there was a strong connection between the remuneration of the board and the company properties such as concentration of property, the type of managing shareholder and the shareholder's contracts. Additionally, board pay was linked to company performance.

\section{Theoretical Framework}

\subsection{Agency Theory}

Executive compensation is underpinned by a number of theories, the most prominent of which are discussed in this section. According to the agency theory, managers are inclined to focus on creating their own wealth rather than maximizing shareholder wealth (Jensen \& Meckling, 1976). Various corporate governance codes and rules have been put in place over time to better align the interests of managers and agents.

Executive compensation could be a tool to tackle the Agency's problems, but it could also be seen as part of the issue. According to the ideal contracting theory, incentives could be used to encourage managers to maximize shareholder wealth. The management energy strategy postulates that managers are in a situation to partially influence their pay. As such, they could benefit from exorbitant packages that are not necessarily connected to their results (Bebchuk \& Fried, 2003; Edmans \& Gabaix, 2009).

\subsection{Signaling Theory}

Executive Directors have an incentive to tackle information asymmetry by willingly publishing data on the market. According to signaling theory, Lang and Lundholm (1993) and Verrecchia (1983) indicate that businesses were better off by releasing both poor and good news to the market in order to prevent being penalized by mispricing their stocks. Companies 
tend to publish excellent news more comprehensively and more quickly than bad news (Wallace \& Naser 1995).

Executive Directors have a greater incentive to reveal data on improvements than to reduce the connection between their individual remuneration and results. This may signal to the industry that managers are working hard for shareholders and deserve their remuneration and additional increases (Abdul Malak, 2015).

\section{Proposed Conceptual Framework}

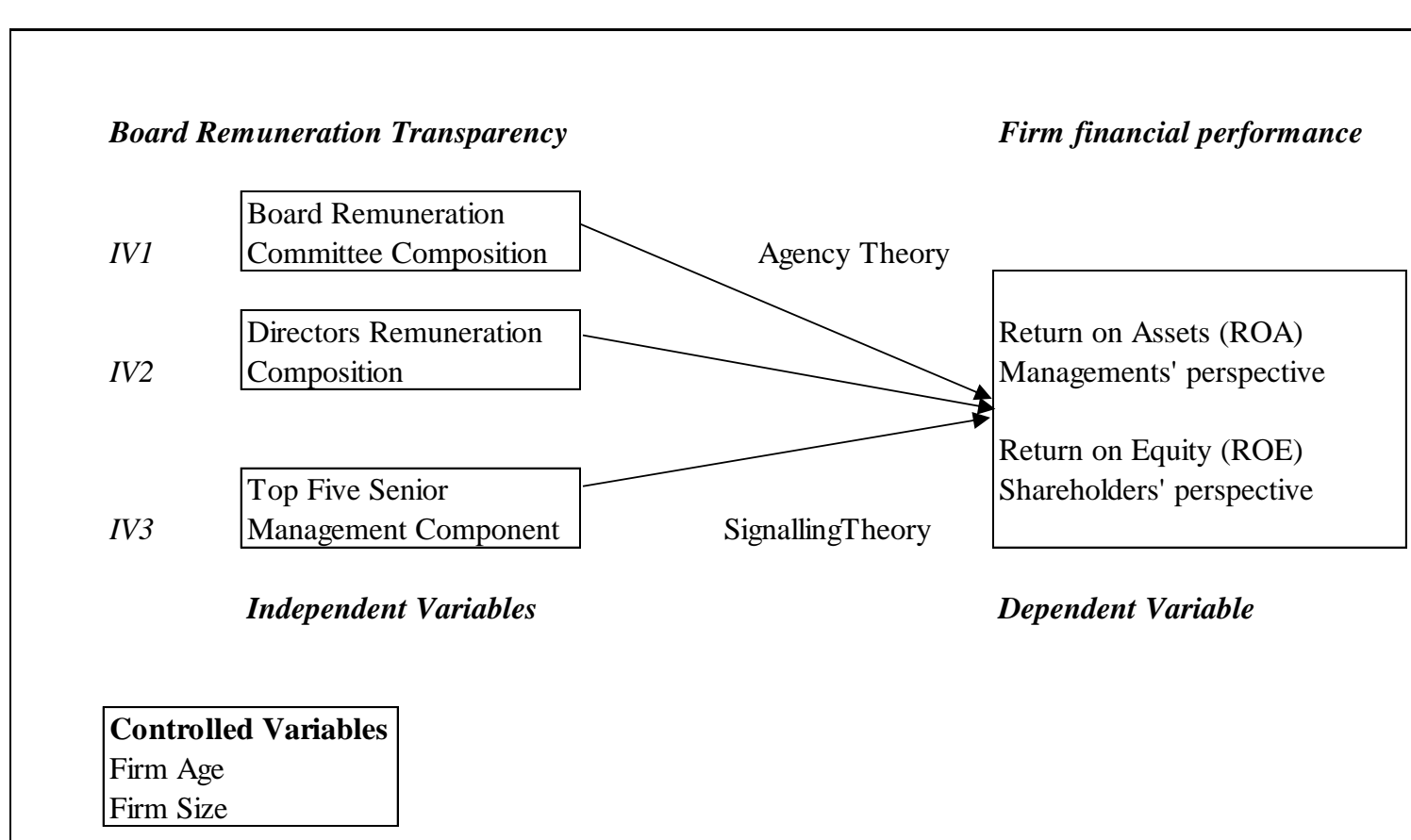

Figure 1. Proposed Conceptual Framework

\section{Dependent Variable - Firm Performance (Return on Equity and Return on Assets)}

The equity return is defined as the extent to which the company produces ROE for its owners, equivalent to the net profit divided by the book value of shareholders. The shareholder's equity usually comprises the value of assets which may be disbursed to shareholders (Richard, Devinney, Yip and Johnson, 2009).

In the literature currently available, a number of indices, including the return on assets (ROA) (Huang, Oua, Chena, \& Lin 2006 ; Khanna \& Palepu, 2000), return-on-equity (ROE), Tobin Q (Sarkar \& Sarkar, 2000), return on capital and operational profits margin, 2005 ; Khanna \& Palepu, 2000); (MBVR) market-by-call ratio.

Indicators like ROA and ROE are accounting-based profitability measures, while Tobin Q and MBVR are inventory market-based measurements. Accounting-based measurements reflect previous financial performance, while market-based performance measures.

While ROA was chosen as a performance indicator, it would explain only how efficiently 
resources were used by the company to deliver profits, it is not the only determinant of the company's well-being. In order to produce greater revenue that will satisfy the shareholders of the company, the company must invest in shares otherwise than using assets. The use of equity return (ROE) as a strong performance measure can thus be encouraged. It can be difficult to use ROE, however.

If investors are not cautious and unpleasant surprises, it can distract attention from the corporate foundations. Companies can use economical approaches to artificially maintain good ROE for some time and to hide declining fundamental performance of companies.

The increased debt levy and the buybacks funded by accumulated money may help maintain an enterprise's ROE, despite a reduction in operating profitability. The ROA and the ROE are calculated and therefore are not based on market-drifting variables on the basis of the balance sheet and other financial statements of the company. Based on investor expectations, the balance sheet announcements may also affect bursary policies (Chaudhuri, Kumbhakar \& Sundaram 2016).

\section{Hypotheses of the Study}

Hypothesis 1(a): Board Remuneration Committee Composition has positive impact on firm financial performance during the MCCG 2012 era.

Hypothesis 1(b): Board Remuneration Committee Composition has positive impact on firm financial performance during the MCCG 2017 era.

Hypothesis 2(a): Directors Remuneration Composition has positive impact on firm financial performance during the MCCG 2012 era.

Hypothesis 2(b): Directors Remuneration Composition has positive impact on firm financial performance during the MCCG 2017 era.

Hypothesis 3(a): Top Five Senior Management Remuneration Component has positive impact on firm financial performance during the MCCG 2012 era.

Hypothesis 3(b): Top Five Senior Management Remuneration Component has positive impact on firm financial performance during the MCCG 2017 era.

\section{Proposed Models for Future Empirical Testing}

Against this background, and in line with the objectives of this study the following models are proposed for future empirical testing:

\section{Model 1:}

$$
\mathrm{ROE}=\beta 0+\beta 1 B R C C+\beta 2 D R C+\beta 3 T F S M+\varepsilon i t
$$

Whereas

$\mathrm{ROE}=$ Return on Equity for measuring accounting performance of the Malaysian oil and gas 
PLCs

$\mathrm{ROA}=$ Return on Assets for measuring accounting performance of the Malaysian oil and gas PLCs

BRCC $=$ Board Remuneration Committee Composition

DRC $=$ Directors Remuneration Composition

TFSM = Top Five Senior Management Remuneration Component

eit $=$ Error term

Model 2:

$$
\mathrm{ROA}=\beta 0+\beta 1 B R C C+\beta 2 D R C+\beta 3 T F S M+\varepsilon i t
$$

\section{Content Validity}

Measuring parameters are identified from the various measuring techniques available under the Malaysian Corporate Governance Code 2012 (MCCG2012), the Malaysian Corporate Governance Code 2017 (MCCG2017) and preliminary corporate governance studies.

\section{Scope and Methodology of the Study and Operationalization of Variables}

In this research sample, the listed public companies published in Bursa Malaysia annual reports or integrated reports from 916 Malaysian PLCs will be examined.

From 2016 to 2018 the information will be collected. In this research, Bursa Malaysia offers a deliberate sample of 34 publicly listed petroleum and gas companies. This research includes descriptive statistics, regression analysis methods and quantitative content analysis in the evaluation of the annual reports. 2016 has been chosen because MCCG 2012 remains efficient and mature.

The year 2017 has been chosen as the MCCG 2017 and companies are transitioning from MCCG 2012 to the 2017 MCCG and the most likely changes introduced by MCCG 2017 have not yet been implemented.

The MCCG 2018 was chosen to take effect on the impact of the changes launched in MCCG 2017 and to gradually transpose the new code. Thus, the researchers will have the opportunity to distinguish the pre and post-impact effects of MCCG 2017 over the course of this three-year period.

The most popular and widely used method for analyzing content is research and reporting (Zahid \& Ghazali 2015; Boesso \& Kumar 2007). Content analysis. Qualitative and quantitative measurements can also be carried out in content analyses. A more reliable 


\section{Macrothink Institute}

analysis is the quantitative content analysis (Zahid and Ghazali, 2015; Day and Woodward, 2009). The quantitative content analysis procedure will be used in the current study.

The coding of data in accordance with the method for content analysis is based on the themes, words or items in the data (Nilsson,2016; Collins and Hussey, 2014).

A scoring system is used for determining the degree to which the items were reported during classification. In order to determine the appropriate number of points, the score system was based on a revision of previous studies that used content analysis. The four-point systems used by Larsson and Ringholm (2014) and Serafeim (2014) were the Wang, Song and Yao systems (2013). They used a three-point system. The two-point systems used by Boiral (2013) and Setia et al. (2015).

This study uses a system similar to previous Nilsson's Integrated Reporting research (2016), in which a certain difference between businesses can be achieved while remaining a timely method. Table 1 Table 2 and Table 3 shows the system used and the cry-ria used.

Table 1. A New Board Remuneration Committee Composition Scoring Index

\begin{tabular}{l}
\hline Board Remuneration Committee Composition (Malaysian Securities Commission, 2017) \\
* Only Non-Executive Directors \\
* Majority Independent Directors \\
* Directors who are shareholders abstain from voting at AGMs to approve their own fees \\
*Executive Directors should not be involved in deciding own remuneration
\end{tabular}

Table 2. A New Board Remuneration Composition Transparency Scoring Index

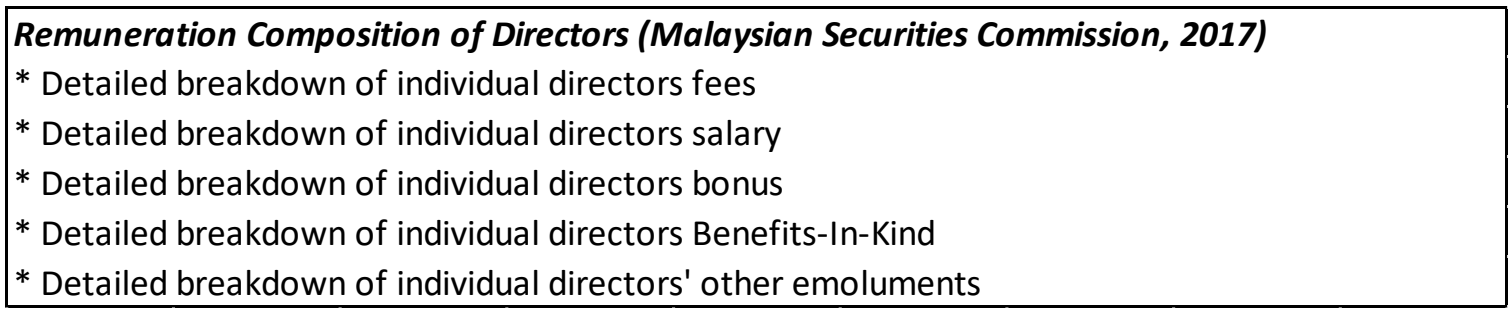

Table 3. A New Top Five Senior Management Remuneration Transparency Scoring Index

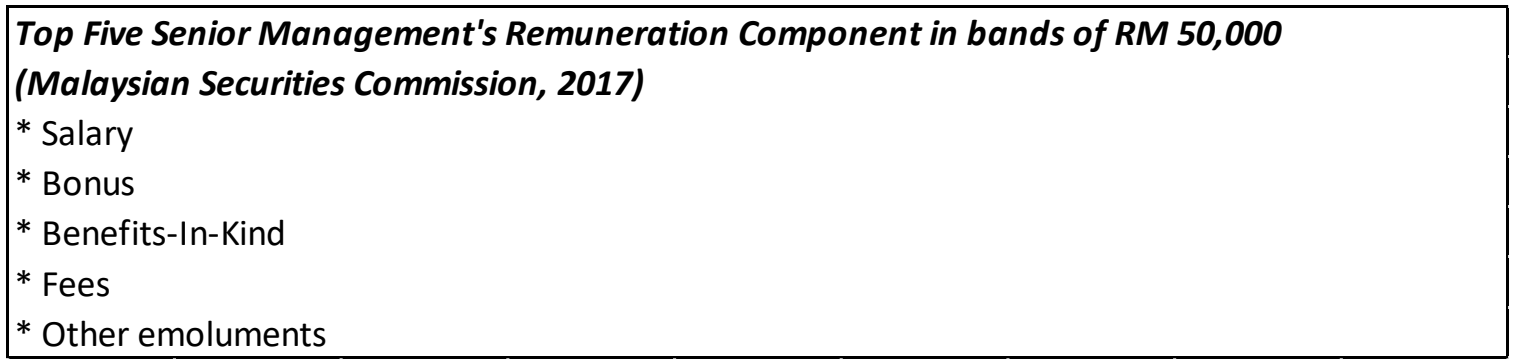




\section{Significance of Study}

The proposed study is of importance to the public companies listing the report in order to make it clear to stakeholders, as well as to make it possible for internally planned use, to legitimise the opinion of the stakeholders and the general public, both by the annual report and in the integrated report preparation. In order to guarantee improvement in corporate governance in PLCs, the application of the 2017 MCCG will take place gradually in 2018.

In terms of methodological significance, the scoring index provides a new frontier for collating data from annual reports and integrated reports. Furthermore, in terms of practical significance, public listed companies may use the scoring index to measure the level of compliance towards MCCG 2017.

\section{Discussion and Conclusion}

The study is only 1 year after the launch of MCCG 2017, which is 2018, when future research will analyze the application beyond a year of the Code's execution. In order to support the reputation of companies, however, this study is going to see any early implementation of the MCCG 2017 by big oil and gas PLCs.

The crude prices boosted to approximately US\$ 70 per barrel after a lengthy slump. In at least four years, 2018 can become the most lucrative year for petroleum and gas businesses. The classic case of observable luck is oil prices. We have examined US oil and gas businesses in specific, as these are the firms most affected by the price of oil. The effects of petroleum prices in this company line were less evident and direct, we excluded businesses which are involved in part or solely in petroleum refining - including Valero Energy, Chevron and Exxon Mobil. The market value of these petroleum and gas manufacturing firms has been increased by 9.9 percent-almost a1-by-1 relationship-by ten percent in petroleum prices. Maybe so many businesses in no other sector are motivated by a single international cost. However, we found more surprising that management compensation follows a comparable pattern. A $10 \%$ increase in petroleum prices, in specific, improves executive compensation by $2 \%$. Executive pay is higher with higher petroleum prices than with lower petroleum prices. This reflects anecdotal proof that the executive compensation criteria change over time. And that during "boom" times, they are quantitative and in "bust" times they are better quality. In other words, US oil and gas officials are reaping great benefits if prices increase and when prices drop, they are not so much punished (Davis and Hausman, 2018).

\section{References}

Adams, R.B. (2012). Governance and the financial crisis. International Review of Finance, 12(1), 7-38. http://dx.doi.org/10.1111/j.1468-2443.2011.01147.x

Aebi, V., Sabato, G., \& Schmid, M. (2010). Risk Management, Corporate Governance, and Bank Performance in the Financial Crisis. 10th GUBERNA European Corporate Governance conference in Brussels (2010) and the University of St. Gallen, January. 
Alchian, A., \& Demsetz, H. (1972). Production, Information Costs, and Economic Organization. American Economic Review, I62, 777-795.

Barontini, R., \& Bozzi, S. (2009). Board compensation and ownership structure: empirical evidence for Italian listed companies. $J$ Manag Gov. http://dx.doi.org/10.1007/s10997-009-9118-5

Carola, F., \& Saks, R.E. (2010). Executive Compensation: A New View from a Long-Term Perspective, 1936-2005. The Review of Financial Studies, 23(5), 2100-2138.

Chen, I. (2012). Corporate Governance and Capital Allocations of Diversified Firms. Journal of Banking and Finance, 36(2), 395-409. http://dx.doi.org/10.1016/j.jbankfin.2011.07.013

Chesney, M., Stromberg, J., \& Wagner, A.F. (2012). Risk-taking incentives and losses in the financial crisis. Working paper, Swiss Finance Institute, Switzerland.

Cheung, Y., Connelly, J.T., Limpaphayom, P., \& Zhou, L. (2007). Do investors really value corporate governance? Evidence from the Hong Kong market. Journal of International Financial Management and Accounting, 18(2), 86-122. http://dx.doi.org/10.1111/j.1467-646X.2007.01009.x

Cullen, M., Kirwan, C., \& Brennan, N. (2012). Comparative Analysis of Corporate Governance Theory: The Agency-Stewardship Continuum. Paper presented at the 20th Annual Conference of the Irish Accounting \& Finance Association, Institute of Technology Tralee, 10-11 May.

Doucouliagos, H., Askary, S., \& Haman, J. (2006). Director's remuneration and performance in Australian Banking. Faculty of Business and Law, Deakin University.

Eisenhardt, K. M. (1989). Agency Theory: An Assessment and Review. International Journal of Management, 5, 341-353. Fahlenbrach, R., \& Stulz, R. M. (2011). Bank CEO Incentives and the credit risk. Journal of Financial Economics, 99(1), 11-26. http://dx.doi.org/10.1016/j.jfineco.2010.08.010

Fama, E. F. (1980). Agency Problems and the Theory of the Firm. The Journal of Political Economy, 88(2), 288-307. http://dx.doi.org/10.1086/260866

Gakeri, J. K. (2013). Enhancing Kenya's Securities Markets through Corporate Governance: Challenges and Opportunities. International Journal of Humanities and Social Science, 3(6), 96-117.

Ghazali, N. A. M. (2010). Ownership structure, corporate governance and corporate performance in Malaysia. International Journal of Commerce and Management, 20(2), 109-119. http://dx.doi.org/10.1108/10569211011057245

Gong, G., \& Li, H. (2007). Outside Directors' Equity-based Compensation and Earnings Management. University of Iowa. Greenbury, R. (1995). Director's Remuneration: Report of a Study Group chaired by Sir Richard Greenbury. European Corporate Governance Institute. 
Gupta, P., Kennedy, D., \& Weaver, S. (2009). Corporate Governance and Firm Value: Evidence from Canadian Capital Markets. Corporate Ownership and Control Journal, 6(3), 293-307.

Haat, M.H., Abdul, R.R., \& Mahenthiran, S. (2008). Corporate governance, transparency and performance of Malaysian companies. Managerial Auditing Journal, 23(8), 744-778. http://dx.doi.org/10.1108/02686900810899518

Haniffa, R. M., \& Cooke, T. E. (2002). Culture, corporate governance and disclosure in Malaysian corporations. $\quad$ ABACUS, 38(3), 317-349. http://dx.doi.org/10.1111/1467-6281.00112

Jensen, M. C. (1993). The Modern Industrial Revolution, Exit and the Failure of Internal Control Systems. The Journal of Finance, 48(3), 831-880. http://dx.doi.org/10.1111/j.1540-6261.1993.tb04022.x

Jensen, M. C. (1976). Meckling WH. Theory of the Firm: Managerial Behavior, Agency Costs and Ownership Structure. Journal of Financial Economics, 3, 305-360. http://dx.doi.org/10.1016/0304-405X(76)90026-X

Kholeif, A. (2008). CEO duality and accounting-based performance in Egyptian listed companies: a re-examination of agency theory predication. Research in Accounting in Emerging Economies, 8, 65-98. http://dx.doi.org/10.1016/S1479-3563(08)08003-1

Lipman, F., \& Hall, S. (2008). Executive compensation best practices. Hoboken, N.J.: John Wiley \& Sons. Lublin, J.S., \& Bulkeley. (2006). WM. IBM ends director stock options, spotlighting popular perk's decline. The Wall Street Journal.

Mashayekhi, B. A., \& Bazaz, M. S. (2008). Corporate governance and firm performance in Iran. Journal of Contemporary Accounting \& Economics, 4(2), 156-172. http://dx.doi.org/10.1016/S1815-5669(10)70033-3

Miyienda, M., Oirere, C. O., \& Miyogo, J. (2012). The relationship between director remuneration and performance of firms listed in the Nairobi Securities Exchange. The International Journal of Social Sciences, 15(1), 1-17.

Mukaila, A. S., Sanda, A. U., \& Garba, T. (2005). Corporate Governance Mechanisms and Firm Financial Performance in Nigeria. Final Report Presented to the Biannual Research Workshop of the AERC, Nairobi, Kenya.

Mulili, M. B., \& Wong, P. (2010). Corporate Governance in Developing Countries. The Case for Kenya. International Journal of Business Administration, 2(1), 1-15.

Müller, V. (2014). Do corporate board compensation characteristics influence the financial performance of listed companies? Procedia-Social and Behavioural Sciences, 109, 983-988. http://dx.doi.org/10.1016/j.sbspro.2013.12.575

Padilla A. (2002). Can Agency Costs Justify the Regulation of Insider Trading?. The 
Quarterly Journal of Austrian Economics, $\quad$ 5, 3-38. http://dx.doi.org/10.1007/s12113-002-1015-6

Pokrashenko, P. (2012). Cost efficiency of Russian banks: the impact of board of directors and executive group. Economics Education and Research Consortium. Working Paper. 12/02E. 2-31.

Ponnu, C. (2008). Corporate governance structures and the performance of Malaysian public listed companies. International Review of Business Research Papers, 4(2), 217-230.

Sami, H., Wang, J., \& Zhou, H. (2011). Corporate governance and operating performance of Chinese listed firms. Journal of International Accounting, Auditing and Taxation, 20, 106-114. http://dx.doi.org/10.1016/j.intaccaudtax.2011.06.005

Scholtz, H. E., \& Smit, A. (2012). Executive remuneration and company performance for South African companies listed on the Alternative Exchange (AltX). SA Business Review, 16(1), 22-38.

Sheikh, N. A., \& Wang, Z. (2012). Effects of corporate governance on capital structure: empirical evidence from Pakistan. Corporate Governance, 12(5), 629-641. http://dx.doi.org/10.1108/14720701211275569

Stanwick, P. A., \& Stanwick, S. D. (2010). The relationship between governance and financial performance: an empirical study of Canadian firms. The Business Review, 16(2), $35-41$.

Turana, J. (2010). Tackle Boardroom Queries on Corporate Governance, BUSINESS DAILY, Apr. 12, 2010. Yatim, P. (2010). Director's Remuneration and Corporate Governance in Malaysia. Universiti Kebangsaan Malaysia.

Zhu, Y, Tian, G. G., \& Ma, S. (2009). Executive compensation, board characteristics and firm performance in China: the impact of compensation committee. 22nd Australasian Finance and Banking Conference (2009: 1-48). Sydney, Australia: Social Science Electronic Publishing, Inc. http://dx.doi.org/10.2139/ssrn.1460590

\section{Copyright}

Copyright for this article is retained by the author(s), with first publication rights granted to the journal.

This is an open-access article distributed under the terms and conditions of the Creative Commons Attribution license (http://creativecommons.org/licenses/by/4.0/). 